\title{
Phytoextraction of Nickel Contaminated Soil with Citric Acid and Humic Acid treatments using Rosemary (Rosmarinus officinalis) Plant
}

\author{
Abdullah Eren* \\ Department of Crops and Animal Production, Artuklu University, Turkey
}

Submission: April 26, 2019; Published: May 24, 2019

*Corresponding author: Abdullah Eren, Department of Crops and Animal Production, Kiziltepe Vocational Training High School, Artuklu University, 47200 Mardin, Turkey

\begin{abstract}
In this study, the removal possibilities of $\mathrm{Ni}$ from contaminated soil using perennial rosemary (Rosmarinus officinalis) plants were investigated. This decontamination process was conducted adding citric acid $\left(\mathrm{C}_{6} \mathrm{H}_{8} \mathrm{O}_{7}\right)$ and humic acid. Increasing dose of Ni $(0,50,100,200$ and $\left.400 \mathrm{mg} \mathrm{Ni} \mathrm{kg}^{-1}\right), 0.005 \mathrm{mM}$ citric acid and $2 \%$ humic acid were added to the test soil in the pots and incubated under controlled conditions for a month. The seedlings of rosemary plant were transferred to the pots and they were grown for 45 days. At the end of the experiments, dry weight of plant tissues and the concentrations of $\mathrm{Ni}$, nitrogen $(\mathrm{N})$, phosphorus $(\mathrm{P})$, potassium $(\mathrm{K})$, calcium $(\mathrm{Ca})$, magnesium $(\mathrm{Mg})$, iron $(\mathrm{Fe})$, zinc $(\mathrm{Zn})$, manganese $(\mathrm{Mn})$, and copper $(\mathrm{Cu})$ were determined. The treatments of citric acid and humic acid were increased the Ni uptake of plants. As a result of the experiments, it has been determined that the rosemary plant has accumulated $189 \mu \mathrm{g} \mathrm{plant}{ }^{-1}$ in $400 \mathrm{mg} \mathrm{Ni} \mathrm{kg}^{-1}$ application, and $246 \mathrm{~g}_{\text {plant }}{ }^{-1}$ in $400 \mathrm{mg} \mathrm{Ni} \mathrm{kg}^{-1}+$ citric acid application and $216 \mu \mathrm{g} \mathrm{plant}^{-1}$ in $400 \mathrm{mg} \mathrm{Ni} \mathrm{kg}^{-1}+$ humic acid application. The results showed that the rosemary plant has the potential phytoextractor plant in decontamination process with citric acid and humic acid.
\end{abstract}

Keywords: Soil pollution; Nickel; Citric acid; Humic acid; Rosmarinus officinalis

\section{Introduction}

The changes in the properties of agricultural soils via human activities (mining activities, application of treated sludge to agricultural soils, usage of fertilizers and pesticides, etc.) are the main factors of increase metal ions concentrations of soils and these release of metal ions in soil has serious effects on living organisms [1,2]. Clean-up, reclamation and decontamination process of metal-contaminated areas are difficult due to metals being non-degradable, unlike organic compounds [3]. Nickel (Ni), has a special place between heavy metals, is a component of $\mathrm{Ni}$ urease, unlike some heavy metals, and are required for some plant species in a small amount ( 0.01 to $5 \mu \mathrm{g} \mathrm{g}^{-1}$ dry weight). However, $\mathrm{Ni}$ is not essential for plant metabolism and can be toxic at high concentrations [4]. Some plant species can accumulate Ni even at high concentration in the above-ground parts and they called as "Ni-phytoextractor" [5]. Phytoextraction is defined as the direct use of green plants for removal or treatment of pollutants for soil, surface waters and groundwater [6]. It is stated that the plant to be used in phytoextraction process should be deep-rooted, have high adaptability to climate change and soil type, and should have the ability to produce abundant green parts to accumulate large amounts of metal ions [7]. It is accepted by many researchers that the phytoremediation method, which is one of the most suitable methods for the biological treatment of heavy metals in soil, is an environmentally friendly and economical way [8-11]. Almost all the different types and varieties of plants have the potential to absorb different metals from the soil. Plants which can tolerate some heavy metals with very high concentrations that can be toxic to any known organism are called "hyperaccumulators" [12]. Synthetic or organic acids (e.g. citric, EDTA, tartaric, pyruvic, fumaric) and other organic acids, which have a low molecular weight, can enhance the accumulation of metals in plant parts by effectively removing heavy metals from the heavy metals contaminated soils [13].

The aim of this study was to determine the phytoextraction capacity of the rosemary (Rosmarinus officinalis) grown in $\mathrm{Ni}$ contaminated soil and the effects of citric acid and humic acid application on phytoextraction capacity of rosemary. In addition, whether the rosemary (Rosmarinus officinalis) plant is a $\mathrm{Ni}$ hyperaccumulator plant or not, and its importance for the use in the phytoextraction process has been investigated with increasing $\mathrm{Ni}$ concentrations. 


\section{Materials and Method}

\section{Materials and experimental setup}

Commercial citric acid monohydrate $\left(\mathrm{C}_{6} \mathrm{H}_{8} \mathrm{O}_{7}\right.$, Merck 100244, $99.5 \%$ purity) was used in the experiments as citric acid $(0.005 \mathrm{mM})$ source and leonardite was used as the source of humic acid (2\%). Leonardite contains humic acid and fulvic acid as $20 \% \mathrm{~W} / \mathrm{W}$ (pH range was $3.5-5.5$ ), and $2 \%$ humic acid has been prepared from leonardite.

In the experiments, rosemary (Rosmarinus officinalis) plant was used as the plant material. This needle-tipped and a smallleaved plant is a member of the Lamiaceae family. This fragrant plant, which is approximately $1-2 \mathrm{~m}$ in length, does not spill its leaves in winter and has a strong aroma like the smell of camphor or eucalyptus [14].

In this study, the rosemary plant was rooted for 3 months with the cutting method. By the way, the soil characterization was determined. The soil samples used in pot experiment was taken from the Artuklu in Mardin-Turkey from 0-30 cm depth, as indicated by Jackson [15]. Then the collected soil was air-dried, passed through a $4 \mathrm{~mm}$ sieve and $2 \mathrm{~kg}$ air-dried soil filled into the pots. The soil sample was passed through a 2-mm mesh sieve for characterization of soil content which was given in Table 1.

Table 1: Physical and chemical properties of soil used in the experiments.

\begin{tabular}{|c|c|c|}
\hline Parameters & Results & References \\
\hline Texture & Clay-loam & {$[16]$} \\
\hline $\mathrm{pH}$ & 7.52 & {$[17]$} \\
\hline $\mathrm{Salt}$ & $0.18 \%$ & {$[18]$} \\
\hline $\mathrm{CaCO}_{3}$ & $8.20 \%$ & {$[19]$} \\
\hline Organic Matter & $2.02 \%$ & {$[20]$} \\
\hline Field Capacity & $29.40 \%$ & {$[21]$} \\
\hline $\mathrm{N}$ & $1.08 \%$ & {$[22]$} \\
\hline $\mathrm{P}$ & $12.6 \mathrm{P}_{2} \mathrm{O}_{5}$ & {$[23]$} \\
\hline $\mathrm{K}$ & $80.1 \mathrm{~K}_{2} \mathrm{O}$ & {$[24]$} \\
\hline $\mathrm{Fe}$ & $20.7 \mathrm{mg} \mathrm{kg}^{-1}$ & \multirow{2}{*}{} \\
\cline { 1 - 2 } $\mathrm{Cu}$ & $4.24 \mathrm{mg} \mathrm{kg}^{-1}$ & \\
\cline { 1 - 2 } $\mathrm{Mn}$ & $58.7 \mathrm{mg} \mathrm{kg}^{-1}$ & \\
\cline { 1 - 2 } & $625]$ \\
\hline $\mathrm{Zn}$ & $6.15 \mathrm{mg} \mathrm{kg}^{-1}$ & \\
\hline $\mathrm{Ni}$ & $3.29 \mathrm{mg} \mathrm{kg}^{-1}$ & \\
\hline
\end{tabular}

The soil texture was determined as clay loam and the soil was slightly saline $(0.18 \%)$, slightly alkaline $(7.52)$, moderately lime (8.20\%) with moderate organic matter content. The nutrient element (N, P, K, Fe, Cu, Mn and Zn) concentrations of the soil were obtained high.

Increasing concentration of $\mathrm{Ni}(0,50,100,200$ and 400mg Ni $\mathrm{kg}^{-1}$ ) with $0.005 \mathrm{mM}$ citric acid and $2 \%$ humic acid were applied to the soil and incubated for 4 weeks. After the incubation period, the rooted plants were transferred to the pots which included
$\mathrm{Ni}$-contaminated soil. The pot experiment was conducted in a greenhouse under controlled conditions for 45 days and they were irrigated with pure water in soil field capacity of $60-80 \%$ during the experiment. The triple randomized block design was used in this experiment.

At the end of the experiment, the plants were harvested approximately $1 \mathrm{~cm}$ above the soil surface and washed with pure water and dried for 48 hours at $65^{\circ} \mathrm{C}$ in a drying cabinet until reaching the constant weight. After taking of dry weights of plants, the samples were grounded in a mill (Retsch RM 200) for plant analysis. Trial results were evaluated green part of plant. The samples of the milled plants were dissolved in the microwave (MarsXpress CEM) with nitric acid $\left(\mathrm{HNO}_{3}\right)$ and $\mathrm{Ni}, \mathrm{P}, \mathrm{K}, \mathrm{Ca}, \mathrm{Mg}$, $\mathrm{Fe}, \mathrm{Zn}, \mathrm{Cu}$ and $\mathrm{Mn}$ concentrations were measured in Inductively Coupled Plasma-Atomic Emission Spectrometer (Agilent 7500ce Model ICP-MS).

\section{Statistical analysis}

The data obtained from the experiments were evaluated according to the factorial trial design using SPSS 22.0 statistical analysis program and grouped with the Duncan test according to [26].

\section{Results and Discussion}

\section{Elemental uptake of rosemary}

The N, P, K, Ca and Mg uptake of rosemary by Ni applications were statistically significant at the level of $p \leq 0.01$ (Table 2). When the effect of different concentration of $\mathrm{Ni}$ applications on the $\mathrm{N}$ concentrations of the plants was examined, decreased values in all applications compared to the control group were observed. Likewise, a reduction of $\mathrm{N}$ concentration in plants with only $\mathrm{Ni}$ applications was observed compared to the control group. Moreover, for $\mathrm{P}$ concentration, an increase in the concentrations of 50 and $100 \mathrm{mg} \mathrm{kg}^{-1} \mathrm{Ni}+$ citrate was determined and then the concentration of $\mathrm{P}$ in plants was decreased. By the way, $\mathrm{P}$ concentration in rosemary increased at the treatment of humic acid compared to control. Additionally, $\mathrm{K}$ concentrations were shown a significantly decreases at the concentrations from 0 to $400 \mathrm{mg} \mathrm{Ni} \mathrm{kg}^{-1}$ in the treatment of $\mathrm{Ni}+$ citric acid compared to $\mathrm{Ni}$ and $\mathrm{Ni}+$ humic acid treatments. Also, while the $\mathrm{K}$ concentration increased at the concentrations of 50 and $100 \mathrm{mg} \mathrm{Ni} \mathrm{kg}^{-1}$ humic acid, decreases were observed at the other concentration of $\mathrm{Ni}$ + humic acid. Meanwhile, Ca concentrations showed a different trend in the concentration of $\mathrm{Ni}+$ citric acid. The Ca concentration in rosemary increased from 0 to $100 \mathrm{mg} \mathrm{Ni} \mathrm{kg}^{-1}$ concentration and the decreases have been observed after this Ni concentration. On the other hand, $\mathrm{Mg}$ concentrations were increased in Ni treatment at the concentration of 50 and $100 \mathrm{mg} \mathrm{Ni} \mathrm{kg}^{-1}$ and in all treatments of $\mathrm{Ni}+$ citric acid, while decreasing in all $\mathrm{Ni}+$ humic acid treatment with compared to the control ( $0 \mathrm{mg} \mathrm{Ni} \mathrm{kg}^{-1}$ ) (Table 2). Dağhan et al. [27] and Brune \& Deitz [28] reported that N, P, and K concentration in tobacco, and $\mathrm{P}, \mathrm{K}$, and Ca concentration in barley was decreased with increasing Ni concentrations, respectively. 
International Journal of Environmental Sciences \& Natural Resources

Table 2: The effect of different concentration of Ni with citric acid and humic acid in soil on N, P, K, Ca and Mg concentrations in rosemary ( $\mathrm{n}=3$ ).

\begin{tabular}{|c|c|c|c|c|c|c|c|}
\hline & \multirow{2}{*}{ Treatments } & \multirow{2}{*}{ Dose $\left(\mathrm{mg} \mathrm{Ni} \mathrm{kg}^{-1}\right)$} & \multirow{2}{*}{ 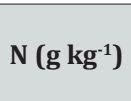 } & $\mathbf{P}$ & $\mathbf{K}$ & Ca & Mg \\
\hline & & & & \multicolumn{4}{|c|}{$\left(\mathrm{mg} \mathrm{kg}^{-1}\right)$} \\
\hline \multirow{16}{*}{$\begin{array}{l}\text { Rosmarinus } \\
\text { Officinalis }\end{array}$} & \multirow{5}{*}{$\mathrm{Ni}$} & 0 & $3.68 \mathrm{a}$ & $45.6 \mathrm{ab}$ & $875 \mathrm{~b}$ & $123 \mathrm{a}$ & $29.5 \mathrm{c}-\mathrm{e}$ \\
\hline & & 50 & $2.83 \mathrm{de}$ & $36.9 \mathrm{~d}$ & $845 \mathrm{bc}$ & $121 \mathrm{ab}$ & $33.8 \mathrm{a}-\mathrm{c}$ \\
\hline & & 100 & $2.59 \mathrm{~d}-\mathrm{f}$ & $37.4 \mathrm{~cd}$ & 789 b-d & $115 \mathrm{bc}$ & $37.8 \mathrm{a}$ \\
\hline & & 200 & $2.49 \mathrm{ef}$ & $28.3 \mathrm{ef}$ & 778 c-e & $106 \mathrm{~d}$ & $28.8 \mathrm{c}-\mathrm{e}$ \\
\hline & & 400 & $2.40 \mathrm{fg}$ & $27.3 \mathrm{f}$ & 749 de & $105 \mathrm{~d}$ & $27.8 \mathrm{de}$ \\
\hline & \multirow{5}{*}{$\mathrm{Ni}+$ Citric Acid } & 0 & $3.58 \mathrm{ab}$ & 45.5 a-c & $1074 \mathrm{a}$ & $89.6 \mathrm{gh}$ & $25.3 \mathrm{e}$ \\
\hline & & 50 & $3.40 \mathrm{ab}$ & $51.3 \mathrm{a}$ & $538 \mathrm{~g}$ & $103 \mathrm{~d}-\mathrm{f}$ & $27.8 \mathrm{de}$ \\
\hline & & 100 & $3.40 \mathrm{ab}$ & $45.8 \mathrm{ab}$ & $461 \mathrm{gh}$ & $125 \mathrm{a}$ & $29.2 \mathrm{c}-\mathrm{e}$ \\
\hline & & 200 & $2.95 \mathrm{~cd}$ & $24.9 \mathrm{f}$ & $427 \mathrm{~h}$ & $111 \mathrm{~cd}$ & $30.0 \mathrm{~b}-\mathrm{e}$ \\
\hline & & 400 & $2.06 \mathrm{~g}$ & $23.6 \mathrm{f}$ & $330_{1}$ & $85.2 \mathrm{~h}$ & $35.0 \mathrm{ab}$ \\
\hline & \multirow{5}{*}{$\mathrm{Ni}+$ Humic Acid } & 0 & $3.54 \mathrm{ab}$ & $36.3 \mathrm{de}$ & 766 c-e & $104 \mathrm{de}$ & $33.6 \mathrm{a}-\mathrm{c}$ \\
\hline & & 50 & $3.27 \mathrm{bc}$ & $49.2 \mathrm{a}$ & 794 b-d & $96.6 \mathrm{e}-\mathrm{g}$ & $30.7 \mathrm{~b}-\mathrm{d}$ \\
\hline & & 100 & $2.65 \mathrm{~d}-\mathrm{f}$ & $50.7 \mathrm{a}$ & $790 \mathrm{~b}-\mathrm{d}$ & $95.5 \mathrm{fg}$ & $29.6 \mathrm{c}-\mathrm{e}$ \\
\hline & & 200 & $2.58 \mathrm{~d}-\mathrm{f}$ & $49.2 \mathrm{a}$ & 692 ef & $93.3 \mathrm{~g}$ & $28.1 \mathrm{de}$ \\
\hline & & 400 & $2.58 \mathrm{~d}-\mathrm{f}$ & $40.5 \mathrm{~b}-\mathrm{d}$ & $637 \mathrm{f}$ & $91.9 \mathrm{gh}$ & $27.9 \mathrm{de}$ \\
\hline & & F & $21.3^{* *}$ & $18.0^{* *}$ & $59.8^{* *}$ & $31.7^{* *}$ & $5.31^{* *}$ \\
\hline
\end{tabular}

$\left.{ }^{* *}\right) p \leq 0.01$ statistically significant within error bounds.

The uptake of Fe, $\mathrm{Zn}, \mathrm{Mn}$, and Cu nutrient elements by rosemary plant from Ni-contaminated soil were statistically significant at the level of $\mathrm{p} \leq 0.01$ (Table 3). While Fe and Mn uptake of rosemary plant was increased with the organic acid treatment compared to the without organic acids treatments, concentrations of Fe, Mn, and $\mathrm{Cu}$ were decreased in rosemary plant with $\mathrm{Ni}$ treatments compared to control.

Table 3: The effect of different concentration of Ni with citric acid and humic acid in soil on Fe, $\mathrm{Zn}, \mathrm{Mn}$ and $\mathrm{Cu}$ concentrations in rosemary ( $\mathrm{n}=3$ ).

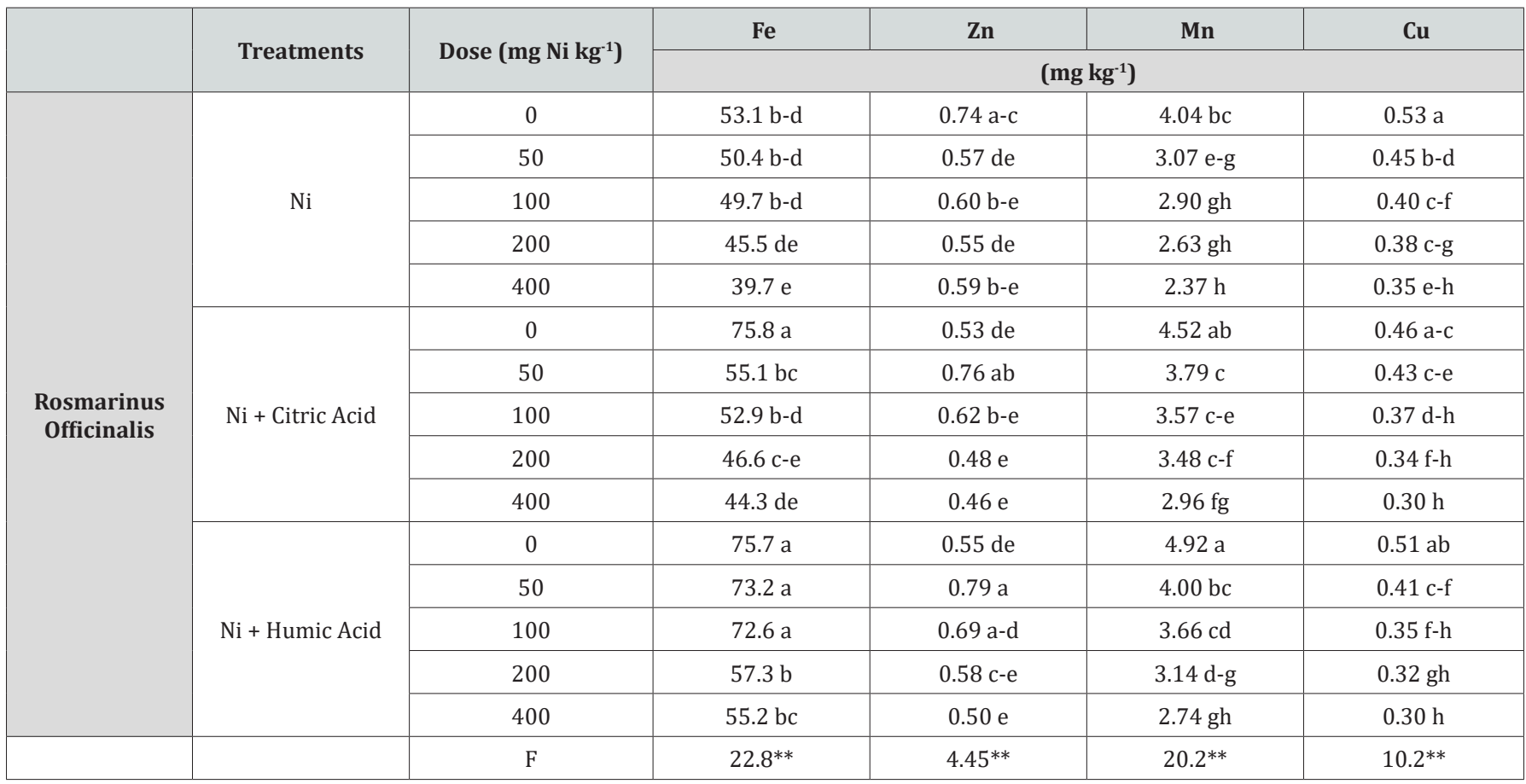

$\left.{ }^{(*}\right) p \leq 0.01$ statistically significant within error bounds. 
The organic acids addition in control groups $\left(0 \mathrm{mg} \mathrm{Ni} \mathrm{kg}{ }^{-1}\right)$ was decreased the uptake of $\mathrm{Cu}$ and $\mathrm{Zn}$ plant compared to without organic acids treatments. On the other hand, Ni treatments were changed the uptake of these metals ( $\mathrm{Fe}, \mathrm{Cu}, \mathrm{Zn}$ and $\mathrm{Mn}$ ). Zinc concentration was decreased with $\mathrm{Ni}$ treatments, whereas in $\mathrm{Ni}$ + citric acid treatment the $\mathrm{Zn}$ concentration was increased at the concentration of 50 and $100 \mathrm{mg} \mathrm{Ni} \mathrm{kg}^{-1}$ and in $\mathrm{Ni}+$ humic acid treatments except for $400 \mathrm{mg} \mathrm{Ni} \mathrm{kg}^{-1}$ (Table 3). It has been stated that the concentrations of microelements such as $\mathrm{Fe}, \mathrm{Mn}, \mathrm{Cu}$, and $\mathrm{Zn}$ were decreased at different concentrations of $\mathrm{Ni}$ in different plants [29-31].

\section{Phytoextraction capacity of rosemary}

It was observed that increasing concentration of $\mathrm{Ni}$ with citric acid and humic acid treatments were statistically significant $(\mathrm{p} \leq 0.01)$ in terms of dry weight, Ni concentration, and Ni content of rosemary (Rosmarinus officinalis) plant (Table 4). With the increase of different Ni concentrations, the rosemary plant was showed the reduction in dry weight values in all treatments compared to the control groups. The lowest and the highest dry weights were determined at $400 \mathrm{mg} \mathrm{Ni} \mathrm{kg}^{-1}+$ citrate treatment and at the control group of citrate treatment $\left(0 \mathrm{mg} \mathrm{Ni} \mathrm{kg}^{-1}\right)$ as $1.21 \mathrm{~g}$ and $2.60 \mathrm{~g}$ dry weight, respectively. Ni concentrations and contents [content $=$ dry weight $\mathrm{x}$ concentration] were increased depending on the increased concentration of $\mathrm{Ni}$ that combined treatment with citric acid. The highest $\mathrm{Ni}$ concentration and contents (204mg $\mathrm{Ni} \mathrm{kg}^{-1}$ and $246 \mu \mathrm{g}$ plant $^{-1}$, respectively) were recorded at $400 \mathrm{mg} \mathrm{Ni} \mathrm{kg}^{-1}$ with citric acid treatments. Humic acid treatments were also positively affected $\mathrm{Ni}$ uptake of plants but these accumulations were lower than $\mathrm{Ni}+$ citric acid treatments (Table 4). The citric acid has multidimensional bind properties and more active functional groups (three carboxyl groups and one alcoholic functional group) than humic acid and these functional groups show a good affinity to heavy metals such as Ni. Thus, it was predicted that this result was obtained due to these functional groups, like as [32]. Similar findings were reported by [33]. They stated that citric acid applications on the Ni contaminated soils were increased the Ni concentration and content of plants, while decreasing the biomass. Similarly, an increase in Ni concentration was reported in green parts of the Brassica juncea plant by citric acid application compared to the control plants $[1,34]$.

Table 4: The effects of different concentration of $\mathrm{Ni}$ applications with citric acid and humic acid media on dry mass, Ni concentration and Ni contents in rosemary $(n=3)$.

\begin{tabular}{|c|c|c|c|c|c|}
\hline & Treatments & Dose (mg Ni kg-1) & Dry Weight (g plant ${ }^{-1}$ ) & $\mathrm{Ni}\left(\mathrm{mg} \mathrm{kg}^{-1}\right)$ & Ni Content $\left(\mu\right.$ g plant $\left.^{-1}\right)$ \\
\hline \multirow{16}{*}{$\begin{array}{l}\text { Rosmarinus } \\
\text { Officinalis }\end{array}$} & \multirow{5}{*}{$\mathrm{Ni}$} & 0 & $2.11 \mathrm{bc}$ & $5.12 \mathrm{j}$ & $10.8 \mathrm{f}$ \\
\hline & & 50 & $2.13 \mathrm{~b}$ & 45.11 & $96.4 \mathrm{e}$ \\
\hline & & 100 & $1.51 \mathrm{ef}$ & $84.6 \mathrm{f}$ & $128 \mathrm{de}$ \\
\hline & & 200 & $1.65 \mathrm{~d}-\mathrm{f}$ & $112 \mathrm{e}$ & $186 \mathrm{c}$ \\
\hline & & 400 & $1.46 \mathrm{fg}$ & $130 \mathrm{~d}$ & $189 \mathrm{c}$ \\
\hline & \multirow{5}{*}{$\mathrm{Ni}+$ Citric Acid } & 0 & $2.60 \mathrm{a}$ & $6.59 \mathrm{j}$ & $17.0 \mathrm{f}$ \\
\hline & & 50 & $1.98 \mathrm{bc}$ & $60.4 \mathrm{~h}$ & $119 \mathrm{de}$ \\
\hline & & 100 & $1.97 \mathrm{bc}$ & $67.5 \mathrm{gh}$ & $133 \mathrm{de}$ \\
\hline & & 200 & $1.71 \mathrm{de}$ & $140 \mathrm{bc}$ & $241 \mathrm{ab}$ \\
\hline & & 400 & $1.21 \mathrm{~g}$ & $204 \mathrm{a}$ & $246 \mathrm{a}$ \\
\hline & \multirow{6}{*}{$\mathrm{Ni}+$ Humic Acid } & 0 & $1.87 \mathrm{~cd}$ & $6.43 \mathrm{j}$ & $12.1 \mathrm{f}$ \\
\hline & & 50 & $1.90 \mathrm{~b}-\mathrm{d}$ & $65.7 \mathrm{gh}$ & $125 \mathrm{de}$ \\
\hline & & 100 & $2.05 \mathrm{bc}$ & $71.3 \mathrm{~g}$ & $146 \mathrm{~d}$ \\
\hline & & 200 & $1.55 \mathrm{ef}$ & $131 \mathrm{~cd}$ & $202 \mathrm{bc}$ \\
\hline & & 400 & $1.51 \mathrm{ef}$ & $142 \mathrm{~b}$ & 216 a-c \\
\hline & & $\mathrm{F}$ & $24.7^{* *}$ & $441.6^{* *}$ & $53.2^{* *}$ \\
\hline
\end{tabular}

$\left.{ }^{* *}\right) p \leq 0.01$ statistically significant within error bounds.

It has been reported that the application of chelating agents increases the solubility of heavy metals in soils, thus has a positive effect on increasing the plant extraction and the applications of natural low molecular weight organic acids such as citric and tartaric acid also give positive results [35-37]. A previous study has stated that the soils treated with humic substance can raise the clean-up of heavy metals from contaminated soils and able to prevent their environmental mobility [38].

\section{Conclusion}

In this study, it was found that the citric acid and humic acid treatments to the Ni-contaminated soil were significantly enhanced the phytoextraction capacity of rosemary. It can be concluded that the citric acid and humic acid effects on Ni uptake by rosemary depends on metal-chelate formation. The addition of organic acids to soil leads to an increase in the bioavailability of metals in soil. The organic acid treatments also significantly 
influence the phytoextraction of $\mathrm{Ni}$ from contaminated soil. Citric acid was more effective than humic acid to enhance the phytoremediation capacity due to it is the ability to form strong complexes with metal ions. Also, when the uptake of $\mathrm{Ni}$ by rosemary plants was increased, it was not observed any necrosis and chlorosis in plants.

It should be evaluated together uptake of target metal (e.g. $\mathrm{Ni}$ in Ni-contaminated soil) with other nutrient elements (e.g. Zn, $\mathrm{Mn}, \mathrm{Fe}$ ) to determine the phytoextraction capacity. It is important because the target metal and other nutrients together presence, they enhanced or inhibit the uptake of each other. This may affect plants biomass used in phytoremediation. The dry weights of rosemary reduced at all $\mathrm{Ni}$ concentrations in all treatment groups due to the competition between metal and nutrients. Consequently, rosemary and citric acid can be used together as a potential candidate for phytoextraction of $\mathrm{Ni}$ in contaminated soils.

\section{Acknowledgment}

This work was supported by the project management Unit of Artuklu University (AU) with the project MAÜ.BAP.18.KMYO.007.

\section{References}

1. do Nascimento CWA, Amarasiriwardena D, Xing B (2006) Comparison of natural organic acids and synthetic chelates at enhancing phytoextraction of metals from a multi-metal contaminated soil Environmental Pollution 140(1): 114-123.

2. Jean L, Bordas F, Bollinger JC (2007) Chromium and nickel mobilization from a contaminated soil using chelants. Environmental Pollution 147(3): 729-736.

3. Lasat MM (2002) Phytoextraction of toxic metals: A review of biological mechanisms. J Environ Qual 31(1): 109-120.

4. Seregin IV, Kozhevnikova AD (2006) Physiological role of nickel and its toxic effects on higher plants. Russian Journal of Plant Physiology 53(2): 257-277.

5. Amari T, Lutts S, Taamali M, Lucchini G, Sacch GA, Abdelly C, Ghnaya T (2016) Implication of citrate, malate and histidine in the accumulation and transport of nickel in Mesembryanthemum crystallinum and Brassica juncea. Ecotoxicol Environ Saf 126: 122-128.

6. Muske DN, Gahukar SJ, Akhare AA, Deshmukh SS (2016) Phytoremediation: An Environmentally Sound Technology for Pollution Prevention, Control and Remediation. Advances in Life Sciences 5(7): 2501-2509.

7. Dağhan H (2016) Investigation of Phytoremediation Potential of Tagetes patula L. Plant in Hydroponic Culture Conditions. Soil Water Journal 5(2): 25-31.

8. Baker AJM, McGrath SP, Sidoli CMD, Reeves RD (1994) The possibility of in situ heavy metal decontamination of polluted soils using crops of metal-accumulating plants. Resources Conservation and Recycling 11(1-4): 41-49.

9. Wiszniewska A, Hanus-Fajerska E, Muszynska E, Ciarkowska K (2016) Natural Organic Amendments for Improved Phytoremediation of Polluted Soils: A Review of Recent Progress. Pedosphere 26(1): 1-12.

10. Eren A (2018) Phytoremediation of Copper Contaminated Soil Using Xanthium strumarium L. Plant. Turkish Journal of Agricultural Research 5(2): 152-157.
11. Guo D, Ali A, Ren C, Du J, Li R, et al. (2019) EDTA and organic acids assisted phytoextraction of $\mathrm{Cd}$ and $\mathrm{Zn}$ from a smelter contaminated soil by potherb mustard (Brassica juncea, Coss) and evaluation of its bioindicators. Ecotoxicology and Environmental Safety 167: 396-403.

12. Chen $\mathrm{H}$, Cutright T (2001) EDTA and HEDTA effects on $\mathrm{Cd}, \mathrm{Cr}$, and $\mathrm{Ni}$ uptake by Helianthus annuus. Chemosphere 45(1): 21-28.

13. Wu Z, Gu Z, Wang X, Evans L, Guo H (2003) Effects of organic acids on adsorption of lead onto montmorillonite, goethite and humic acid. Environ Pollut 121(3): 469-475.

14. Coban ÖE, Patır B (2010) Use of Some Spices and Herbs Antioxidant Affected in Foods. Electronic Journal of Food Technologies 5(2): 7-19.

15. Jackson ML (1967) Soil chemical analysis. Prentice Hall, Bombay, India.

16. Bouyoucos GJ (1951) A recalibration of hydrometer for making mechanical analysis of soils. Agronomy Journal 43(9): 434-438.

17. Kacar B (1995) Chemical Analysis of Plant and Soil, III. Soil Analysis. Ankara University Faculty of Agriculture, Education, Research and Development Foundation Publications, No: 3, Ankara.

18. Miller JJ, Curtin D (2008) Chapter 15: electrical conductivity and soluble ions. In: Carter MR, Gregorich EG (Eds.), Soil sampling and methods of analysis. ( $2^{\text {nd }}$ edn), Canadian Society of Soil Science, CRC Press, Boca Raton, USA, pp. 161-171.

19. Loeppert RH, Suarez DL (1996) Carbonate and gypsum. In: Spark DL (Ed.), In Methods of soil analysis. Part 3. Chemical Methods, Madison, Wisconsin, USA, pp. 437-474.

20. Nelson DW, Sommers LE (1996) Total carbon, organic carbon and organic matter. In: Sparks DL. Page AL, Helmke PA, et al. (Eds.), In Methods of Soil Analysis: Part III. Chemical Methods. Madison, Soil Science Society of America, pp. 961-1010.

21. Alpaslan M, Günes A, Inal A (1998) Test Technique. Ankara University Faculty of Agriculture, Publication No: 1502: 455.

22. Bremner JM, Mulvaney CS (1982) Nitrogen-Total 1. Methods of soil analysis. Part 2. Chemical and microbiological properties, (methodsofsoilan2), pp. 595-624.

23. Olsen SR (1954) Estimation of available phosphorus in soils by extraction with sodium bicarbonate. United States Department of Agriculture, Washington, USA.

24. Richards LA (1954) Diagnosis and improvement of saline and alkali soils. United States Department of Agriculture Handbook 60, p. 94.

25. Lindsay WL, Norvell WA (1978) Development of a DTPA soil test for zinc, iron, manganese, and copper. Soil Science Society of America Journal 42: 421-428.

26. Bek Y (1986) Research and Trial Methods. Cukurova University Faculty of Agriculture. Lecture notes. Publication No: 92, Adana.

27. Dağhan H, Uygur V, Köleli N, Arslan M, Eren A (2013) The Effect of Heavy Metal Treatments on Uptake of Nitrogen, Phosphorus and Potassium in Transgenic and Non-Transgenic Tobacco Plants. Journal of Agricultural Sciences 19: 129-139.

28. Brune A, Dietz KJ (1995) A comparative analysis of element composition of roots and leaves of barley seedlings grown in the presence of toxic cadmium, molybdenum, nickel, and zinc concentrations. Journal of Plant Nutrition 18(4): 853-868.

29. Palacios G, Gomez I, Carbonell-Barrachina A, Pedreño JN, Mataix J (1998) Effect of nickel concentration on tomato plant nutrition and dry matter yield. Journal of plant nutrition 21(10): 2179-2191.

30. Kopittke PM, Asher CJ, Menzies NW (2007) Toxic effects of $\mathrm{Ni}^{2+}$ on growth of cowpea (Vigna unguiculata). Plant and Soil 292(1-2): 283289. 
31. Sabir M, Ghafoor A, Zia-ur-Rehman M, Ahmad HR, Aziz T (2011) Growth and metal ionic composition of Zea mays as affected by nickel supplementation in the nutrient solution. International Journal of Agriculture and Biology 13(2).

32. Dakanali M, Kefalas ET, Raptopoulou CP, Terzis A, Mavromoustakos T, et al. (2003) Synthesis and spectroscopic and structural studies of a new cadmium (II)-citrate aqueous complex. Potential relevance to cadmium (II)-citrate speciation and links to cadmium toxicity. Inorg Chem 42(8): 2531-2537.

33. Jean L, Bordas F, Gautier-Moussard C, Vernay P, Hitmi A, et al. (2008) Effect of citric acid and EDTA on chromium and nickel uptake and translocation by Datura innoxia. Environmental Pollution 153(3): 555563.

34. Hsiao KH, Kao PH, Hseu ZY (2007) Effects of chelators on chromium and nickel uptake by Brassica juncea on serpentine-mine tailings for phytoextraction. Journal of hazardous materials 148(1-2): 366-376.
35. Vara Prasad MN, de Oliveira Freitas HM (2003) Metal hyperaccumulation in plants: biodiversity prospecting for phytoremediation technology. Electronic journal of biotechnology 6(3): 285-321.

36. Robinson B, Schulin R, Nowack B, Roulier S, Menon M, et al. (2006) Phytoremediation for the management of metal flux in contaminated sites. Forest Snow and Landscape Research 80(2): 221-224.

37. Evangelou MW, Ebel M, Schaeffer A (2007) Chelate assisted phytoextraction of heavy metals from soil. Effect, mechanism, toxicity, and fate of chelating agents. Chemosphere 68(6): 989-1003.

38. Halim M, Conte P, Piccolo A (2003) Potential availability of heavy metals to phytoextraction from contaminated soils induced by exogenous humic substances. Chemosphere 52(1): 265-275. 